\title{
COMPARATIVE ASSESSMENT OF EXTERNAL COSTS AND POLLUTION TAXES IN BALTIC STATES, CZECH REPUBLIC AND SLOVAKIA
}

\author{
Dalia Štreimikienè, Ilona Ališauskaitè-Šeškienė
}

\section{Introduction}

External costs are the main market failure. Pollution taxes are applied to internalise external costs of atmospheric emissions. Also subsidies to renewables in the form of Feed-in prices are also applied to internalize positive external benefits associated with use of renewable energy sources which are carbon free and has lower life-cycle emissions of classical pollutants in comparison with fossil fuel based energy generation technologies.

One reason to support the promotion of renewable energy comes from the internalization of external costs. Economists have shown that when externalities are present, markets are not efficient unless these external costs are internalized and economic agents take into account these costs when making decisions (Markandya, Longo, \& Petruci, 2008). Internalization of external costs of atmospheric pollution allow not only to increase use of renewable energy sources but also have impact on reduction of emissions into atmosphere.

The aim of this paper is to review and compare external costs of atmospheric pollution and pollution taxes in Baltic States, Czech Republic and Slovakia and assess the level of internalization of external costs and their impact on atmospheric emissions of classical pollutants. Seeking to achieve this aim the main tasks are:

- to review literature on external costs and their internalization;

- to analyse and compare external costs of atmospheric pollution in Baltic States, Czech Republic and Slovakia;

- to analyse and compare atmospheric pollution taxes and other policy measures to internalise external costs of pollution in Baltic States and Czech Republic and Slovakia;

- to analyse development of atmospheric pollution by classical pollutants in Baltic States and Czech Republic and Slovakia;
- to develop policy recommendations based on the main findings of analysis conducted. The methods applied: comparative analysis, graphical analysis, systematization and generalization.

\section{External Costs of Atmospheric Pollution and Their Internalization Policies and Measures}

Almost every energy system, aside from its beneficial consequences to society, causes adverse effects as well (Georgakellos, 2010). In general, costs associated specifically with global warming range widely and differ for fuel (Longo, Markandya, \& Petrucci, 2008). In order to compare the environmental impacts of various electricity production technologies the most widely accepted approach today relies on external costs, i.e. monetary value of damages caused by electricity production (Georgakellos, 2010; Krewitt, 2002). External costs are a significant part of total social costs and, in the case of renewable energy sources (RES), are quite low (Mirasgedis et al., 2000), while major damages, such as atmospheric pollution, acid deposition, adverse health effects of pollution, loss of crop yield and biodiversity, soiling of building facades, accelerated corrosion of materials, and various climate change impacts caused by the production of traditional electricity are not reflected in the prices of fossil fuels (Maca, Melichar, \& Scasny, 2012; Longo, Markandya, \& Petrucci, 2008; Bridges et al., 2015; Streimikiene \& Alisauskaite-Seskiene, 2014; Vasauskaite \& Streimikiene, 2014). Externalities occur at all stages of a fuel cycle (Fouquet et al., 2001), yet path to assessing externalities is mined with difficulties and uncertainties: it can be reduced by improving fuel cycles, switching between fuel cycles, a more efficient end-use of energy and reductions in energy consumption (Fouquet et al., 2001). Nonetheless, ultimate 
goal of externalities valuation is achieved when economically efficient allocation of resources is being made - through the integration of externalities in energy prices (Fouquet et al., 2001). This particular integration or so-called internalization of external costs into the full energy production cost has been considered an efficient policy instrument for reducing negative impacts of energy supply and use (Rafaj \& Kypreos, 2007). Furthermore, internalization of external costs can be seen as major reason to support the promotion of renewable energy. Economists have shown that when externalities are present, markets are not efficient unless these external costs are internalized and economic agents take into account these costs when making decisions (Markandya, Longo, \& Petruci, 2008). Furthermore, if the market does not reflect all the costs of damage made by traditional fuel energy, market prices do not provide the right signals for economic agents and thus cannot ensure optimal allocation of scarce resources (Maca, Melichar, \& Scasny, 2012).

Although a significant research effort in measuring external costs caused by electricity production has been made (European Commission, 1998; Krewitt, 2002; European Commission, 2003; Markandya, 2003; European Commission, 2005), the implementation of appropriate internalization strategies is still hampered by a lack of reliable external cost data (Krewitt, 2002). It is usually the governments' role to step in to ensure prices are right through certain types of regulation (Maca, Melichar, \& Scasny, 2012). Moreover, extent to which prices are corrected depends on the degree to which the external costs are internalized). Different internalization measures can be applied in order to internalize external cost into the price of fossil fuel energy. One of them is subsidies, which have been widely used to address externalities (Longo, Markandya, \& Petrucci, 2008). These subsidies to renewables in the form of feed-in tariffs are widely applied and are among major instruments used by public authorities to support renewable electricity supplies in their infant stages (Blumberga et al., 2014; Verbruggen \& Lauber, 2012). These types of tariffs are structured as fixed-price tariff, which guarantee electricity operators a set price for electricity sold to the grid, or as premium tariff, which adds a definite bonus to the wholesale market price perceived by generators (Blumberga et al., 2014). Well-designed feed-in tariff systems for renewable energies with guaranteed access to the grid have proven the strongest reliability and success (Fouqet, 2013). Other types of RES support policies exist, such as tradable certificates, tax incentives and investment grants, net metering policies, and tendering schemes all of which are applied in European countries separately and in combination with other policy incentives (Blumberga et al., 2014), however, feed-in tariffs are the most widespread promotion scheme in Europe for electricity made of RES (del Rio \& Gual, 2007). Furthermore, European countries have increased their use of environmental tax instruments by designing new tax bases, like taxes on sulfur dioxide, plastic bags, solid waste and batteries (ChiroleuAssouline \& Fodha, 2014). These pollution taxes are applied to reduce other tax distortions in the economy (Parry, 1995) emissions i.e. to internalise external costs of atmospheric emissions and it provide public revenues which can be recycled (Chiroleu-Assouline \& Fonha, 2014). Economists agree, in concept, pollution taxes are the most cost-effective means of reducing pollution, nonetheless it remains unpopular mostly due to public distrust of politicians to spend environmental taxes solely on environmental measures and issues of tax distribution - there is concern such a tax burden will be unfairly distributed (Hsu, Walters, \& Purgas, 2008).

In the following sections of paper external costs of atmospheric emissions will be compared among Baltic States and Czech Republic and Slovakia and the level of external costs internalization in these countries will be assessed by comparing pollution taxes and feed-in tariffs applied for RES. Dynamics of atmospheric emissions will be compared among Baltic States, Czech Republic and Slovakia in order to define to which extend the internalization of external costs have impact on reduction of atmospheric emission in five analyzed countries.

\section{External Costs of Atmospheric Pollution in Baltic States, Czech Republic and Slovakia}

Seven major types of damages have been assessed within ExternE methodology during CASES project (CASES, 2008). The main categories are human health (fatal and nonfatal effects), effects on crops and materials. 
The impact pathway approach - and coming along with this approach, the EcoSense model, an integrated software tool for environmental impact pathway assessment - was developed within the ExternE project series and represents its core (European Commission, 1998; European Commission, 2003; European Commission, 2005). Impact pathway assessment is a bottom-up-approach in which environmental benefits and costs are estimated by following the pathway from source emissions via quality changes of air, soil and water to physical impacts, before being expressed in monetary benefits and costs. The use of such a detailed bottom-up methodology is necessary, as external costs are highly site-dependent. Two emission scenarios are needed for each calculation, one reference scenario and one case scenario. The background concentration of pollutants in the reference scenario is a significant factor for pollutants with non-linear chemistry or nonlinear dose-response functions. The estimated difference in the simulated air quality situation between the case and the reference situation is combined with exposure response functions to derive differences in physical impacts on public health, crops and building material. Not only local damages have to be considered air pollutants are transformed and transported and cause considerable damage hundreds of kilometers away from the source. So local and European wide modelling was performed during ExternE and its extensions. The currently available values for classical air pollutants correspond to an average height of release. Results are available for emission of $\mathrm{NH} 3$ NMVOC, NOx PPMco, PPM25 SO2. For new EU member states such as Lithuania, Latvia, Estonia, Czech Republic and Slovakia external costs of atmospheric pollution were assessed first time (CAES, 2008). Since the background concentration of $\mathrm{NH} 3, \mathrm{NMVOC}, \mathrm{SO} 2$ and $\mathrm{NOx}$ influences the creation of secondary pollutants there are two further distinctions into values corresponding to conditions in 2010 and values corresponding to possible conditions in 2020 were developed during aforementioned project. It is assumed that in most cases the emissions in 2020 are lower than in 2010. It has to be emphasised that because of non-linear atmospheric chemistry and because of different background concentrations of e.g. NOx and NMVOC, especially with regard to ozone there can occur large differences in [Euro per ton] values. Even negative external costs can occur for NOx emission in 2010 regarding ozone. It is recommendable, especially with regard to cost benefit analysis for future measures to use the set corresponding to the conditions in 2020 to include the "real" effect of an emission reduction in the future. The values have been derived by simulation of a certain emission reduction in different regions. This has been done for all pollutants from "all sources (e.g. including transport, industry, domestic firing systems, but also combustion plants), and for reduction of emissions of primary particles, $\mathrm{SO} 2$ and $\mathrm{NOx}$ (e.g. combustion in power plants) only. Further processing of the results allows [Euro per ton] values corresponding to low and high release height. In Table 1 the external costs values corresponding to "Average Height of Release" are presented in Baltic States, Czech Republic and Slovakia and EU-27 average in 2010.

As one can see from Table 1 the highest external costs of atmospheric emissions can be noticed on Czech Republic following by Slovakia. The lowest external costs were determined in Lithuania and Estonia however in Estonia human health and loss of biodiversity costs related to $\mathrm{NH} 3$ are the highest among Baltic States. Lithuania distinguishes with quite high human health and biodiversity loss costs related to NOx comparing with other Baltic States. Countries having higher external costs of atmospheric emissions are supposed to have higher pollution taxes aiming at internalization of external costs of atmospheric emissions. Therefore in the following section of paper pollution taxes for the same atmospheric pollutants will be compared among five EU member states.

\section{Pollution Taxes in Baltic States, Czech Republic and Slovakia}

Air pollution taxes are important flexible pollution reduction measure in energy sector as energy sector is the major sources of classical pollutants (SO2, NOx, Particulates, $\mathrm{CO}$ ) which are usually being charged by air pollution taxes in major EU member states and other countries all over the world (Chiroleu-Assouline \& Fodha, 2014). Pollution taxes applied for classical pollutants are the main policies and measures to internalize external costs of energy generation (Parry, 1995; Longo, Markandya, \& Petrucci, 2008; Georgakellos, 2010; Markandya, 2003). 
Tab. 1:

External costs of atmospheric emissions of classical pollutants in 2010 and 2020, EUR/t - Part 1

\begin{tabular}{|c|c|c|c|c|c|c|}
\hline & EU-27 average & $\begin{array}{c}\text { Czech } \\
\text { Republic }\end{array}$ & Estonia & Lithuania & Latvia & Slovakia \\
\hline \multicolumn{7}{|c|}{2010} \\
\hline \multicolumn{7}{|c|}{ Human Health } \\
\hline $\mathrm{NH} 3$ & 9,482 & 16,783 & 5,103 & 4,348 & 4,825 & 15,094 \\
\hline NMVOC & 584 & 584 & 163 & 326 & 296 & 389 \\
\hline NOx & 5,591 & 7,302 & 1,481 & 3,966 & 2,590 & 7,856 \\
\hline PPMco & 1,325 & 1,009 & 165 & 390 & 342 & 842 \\
\hline PPM25 & 24,410 & 25,208 & 6,159 & 10,969 & 8,844 & 21,640 \\
\hline $\mathrm{SO} 2$ & 6,070 & 7,235 & 3,392 & 4,412 & 3,854 & 6,696 \\
\hline \multicolumn{7}{|c|}{ Loss of Biodiversity } \\
\hline $\mathrm{NH} 3$ & 3,266 & 5,079 & 3,188 & 2,229 & 2,980 & 5,227 \\
\hline NMVOC & -67 & -83 & -29 & -28 & -34 & -56 \\
\hline NOx & 903 & 1,341 & 676 & 590 & 638 & 1,077 \\
\hline PPMco & 0 & 0 & 0 & 0 & 0 & 0 \\
\hline PPM25 & 0 & 0 & 0 & 0 & 0 & 0 \\
\hline $\mathrm{SO} 2$ & 177 & 399 & 167 & 139 & 133 & 332 \\
\hline \multicolumn{7}{|c|}{ Crops: Regional: crops $\mathrm{N}$ deposition \& crops $\mathrm{O} 3$} \\
\hline $\mathrm{NH} 3$ & -183 & -126 & -7 & -11 & -8 & -129 \\
\hline NMVOC & 189 & 136 & 30 & 35 & 40 & 93 \\
\hline NOx & 328 & 399 & 84 & 129 & 119 & 458 \\
\hline PPMco & 0 & 0 & 0 & 0 & 0 & 0 \\
\hline PPM25 & 0 & 0 & 0 & 0 & 0 & 0 \\
\hline $\mathrm{SO} 2$ & -27 & -43 & -11 & -14 & -11 & -20 \\
\hline \multicolumn{7}{|c|}{ Crops: SO2 } \\
\hline NOx & 71 & 127 & 31 & 74 & 47 & 163 \\
\hline $\mathrm{SO} 2$ & -13 & -14 & -9 & -28 & -16 & -6 \\
\hline \multicolumn{7}{|c|}{ Materials: SO2\&NOx } \\
\hline NOx & 71 & 127 & 31 & 74 & 47 & 163 \\
\hline SO2 & 259 & 498 & 95 & 187 & 125 & 469 \\
\hline
\end{tabular}

\begin{tabular}{l|r|r|r|r|r|r}
\hline Human Health & 5,837 & 10,719 & 3,323 & 2,371 & 2,901 & 9,200 \\
\hline NH3 & 238 & 151 & 26 & 56 & 35 & 102 \\
\hline NMVOC & 6,620 & 10,106 & 2,064 & 4,653 & 3,294 & 10,718 \\
\hline NOx & 1,381 & 1,040 & 190 & 397 & 342 & 845 \\
\hline PPMco & 24,191 & 23,992 & 7,279 & 11,169 & 9,371 & 22,057 \\
\hline PPM25 & 6,673 & 8,747 & 3,653 & 5,017 & 4,343 & 7,598 \\
\hline SO2 & & & & & & \\
\hline
\end{tabular}




\section{Tab. 1: External costs of atmospheric emissions of classical pollutants} in 2010 and 2020, EUR/t - Part 2

\begin{tabular}{|c|c|c|c|c|c|c|}
\hline & EU-27 average & $\begin{array}{c}\text { Czech } \\
\text { Republic }\end{array}$ & Estonia & Lithuania & Latvia & Slovakia \\
\hline \multicolumn{7}{|c|}{ Loss of Biodiversity } \\
\hline $\mathrm{NH} 3$ & 3,295 & 5,273 & 3,286 & 2,278 & 3,093 & 5,482 \\
\hline NMVOC & -48 & -72 & -25 & -25 & -27 & -48 \\
\hline NOx & 868 & 1,280 & 642 & 557 & 595 & 987 \\
\hline $\mathrm{SO} 2$ & 192 & 418 & 189 & 143 & 134 & 343 \\
\hline \multicolumn{7}{|c|}{ Crops: Regional: crops $\mathrm{N}$ deposition \& crops $\mathrm{O} 3$} \\
\hline $\mathrm{NH3}$ & -183 & -126 & -4 & -10 & -7 & -132 \\
\hline NMVOC & 103 & 62 & 14 & 16 & 17 & 45 \\
\hline NOx & 435 & 448 & 74 & 104 & 96 & 428 \\
\hline $\mathrm{SO} 2$ & -41 & -75 & -13 & -16 & -12 & -39 \\
\hline \multicolumn{7}{|c|}{ Crops: SO2 } \\
\hline $\mathrm{SO} 2$ & -13 & -14 & -9 & -28 & -16 & -6 \\
\hline \multicolumn{7}{|c|}{ Materials: SO2\&NOx } \\
\hline $\mathrm{NOx}$ & 71 & 127 & 31 & 74 & 47 & 163 \\
\hline $\mathrm{SO} 2$ & 259 & 498 & 95 & 187 & 125 & 469 \\
\hline
\end{tabular}

The higher tax rates on classical pollutants should have positive impact on reduction of atmospheric emissions (Foquet et al., 2001). However there are other policies and measures aiming at internalization of externalities related to atmospheric pollution in energy generation. These policies are aiming to promote renewable energy sources via subsidies and grants by internalising positive externalities or external benefits (Fagiani et al., 2014; Streimikiene \& Alisauskaite-Seskiene, 2014; Streimikiene \& Balezentiene, 2012).

The tax rates for the main pollutants discharged from stationary sources of pollution is set for one tonne of pollutants discharged into the environment. The tax rates for pollutants discharged into the atmosphere in analysed countries are presented in Table 2.

As one can see from information provided in Table 2 the highest rates for classical pollutants in energy sector are being applied in Estonia and Lithuania though these countries distinguishes with the lowest external costs of atmospheric emissions. The lowest rates for classical pollutants are being applied in Czech Republic and Latvia. Therefore Czech Republic having the highest external costs of atmospheric emissions among analysed countries at the same time had the lowest pollution taxes for the corresponding pollutants in 2015.

In Figure 1 the dynamics of revenues from Pollution taxes as percentage of GDP in Baltic States, Czech Republic and Slovakia are presented.

Comparing revenues from pollution taxes as the percentage of GDP between analysed countries one can noticed that the highest share of pollution taxes to GDP is in Slovakia and Estonia. The lowest share is in Latvia (Fig. 3). The steep increase of the share of pollution taxes as percentage of GDP in Slovakia can be noticed in year 2011. This indicates that country is looking forward to green budget reform. In Latvia pollution taxes are very low and do not represent comparable share of GDP for comparative analysis between selected member states. Also very low revenues of pollution taxes to GDP are in Lithuania and Czech Republic. The low pollution tax rates in Czech Republic corresponds to low share of revenues from pollution taxes being applied in this country. 
Tab. 2:

Air pollution tax rates in Baltic States, Czech Republic and Slovakia, valid since 2015, EUR/t

\begin{tabular}{l|r|r|r|r|r} 
& Czech Republic & \multicolumn{1}{c|}{ Slovakia } & \multicolumn{1}{c}{ Lithuania } & \multicolumn{1}{c}{ Latvia } & Estonia \\
\hline NH3 & 38.50 & 66.38 & 4.00 & 18.50 & 122.32 \\
\hline CO & 23.10 & 32.00 & 24.00 & 7.83 & 7.70 \\
\hline Heavy metals & 769.90 & $1,280.20$ & $3,855.00$ & $1,138.30$ & $1,278.00$ \\
\hline NOx & 30.80 & 48.01 & 196.00 & 85.37 & 122.32 \\
\hline PPM25, PPMco & 115.50 & 160.00 & 61.00 & 75.00 & 146.16 \\
\hline SO2 & 38.50 & 64.01 & 104.00 & 85.37 & 145.50 \\
\hline NMVOC & 76.99 & 66.38 & 4.00 & 85.37 & 122.32 \\
\hline
\end{tabular}

Source: EUROSTAT

\section{Fig. 1: Dynamics of revenues from pollution taxes in Baltic States and Czech Republic and Slovakia as the percentage of GDP}

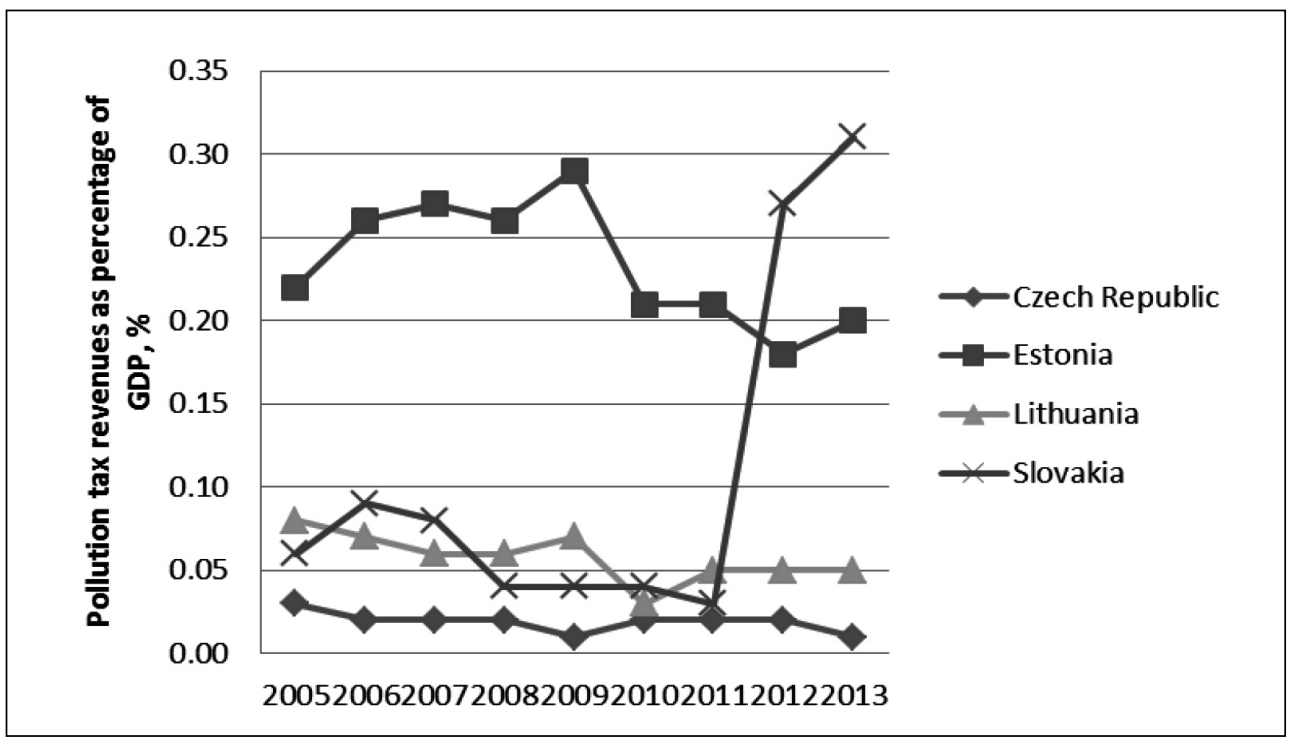

Source: own

There are other opportunities to internalize external costs of atmospheric pollution, i.e. to apply subsidies in the form of feed-in prices for renewable electricity therefore in the next section of the paper the feed-in prices for RES will be compared among Baltic States, Czech Republic and Slovakia.
4. Feed-in Price and Other Measures to Internalize External Costs of Atmospheric Pollution in Baltic States, Czech Republic and Slovakia

As it was already mentioned in previous sections of the paper the Governments are implementing 
various policies to promote renewable energy and to internalize positive externalities related to renewable energy (Fouquet, 2013; Longo, Markandya, \& Petrucci, 2008; Maca, Melichar, \& Scasny, 2012; Rafaj \& Kypreos, 2007; Streimikiene \& Sarvutyte-Grigaliuniene, 2012). Renewable electricity policy mechanisms generally can be categorized into price-based and quantity-based policies (Blumberga, 2014). In price-based instruments, the regulator sets a price for a specific variable. The example can be situation, then generators of renewable energy receive financial support in terms of a subsidy per kilowatt of capacity installed, a payment per kilowatt hour produced and sold or a fixed premium above the electricity market price. In quantity-based policies, the desired level of outcome is set and an artificial market is created in which participants act to fulfil the policy target. These systems operates under the principle that a defined member of the electricity supply chain (consumer, generator or supplier) has to present a fixed minimum quantity of certificates originated per megawatt hour of renewable electricity generated (Verbruggen \& Lauber, 2012). Feed-in tariffs are among major instruments used by public authorities to support renewable energy. They are the most popular RES-E support scheme in the European countries (Del Rio \& Gual, 2007). A feed-in tariff may be structured as either a fixed-price tariff thus guaranteeing electricity operators a set price for electricity sold to the grid, or a premium tariff, which adds a definite bonus to the wholesale market price perceived by generators. The duration, over which the tariff is paid, as well the tariff amount varies between policies applied in countries. Some countries have introduced a mechanism to gradually reduce the tariff rate thus adapting to increasing economic viability of RES-E technologies over time (Jenner, Groba, \& Indvik, 2013). Other types of RES-E support policies include: tradable certificates, tax incentives and investment grants, net-metering policies, and tendering schemes all of which are applied in European countries separately and in combination with other policy incentives. In Table 3 the current rates of Feed-in prices for renewable electricity are presented for Baltic States, Czech Republic and Slovakia.
As one can see from Table 3 analysed countries have various Feed-in tariffs applied for various renewable energy technologies and various type and capacities of PP. In Czech Republic the highest Feed-in tariffs in 2014 were applied for biogas PP with installed capacity up to $100 \mathrm{~kW}-12.9 € \mathrm{c} / \mathrm{kWh}$. The lowest Fedin tariff was applied for biomass (4.8 €c/kWh). Tariff for biomass energy in Czech Republic varies according to the technology used from 4.8 to $12.1 € \mathrm{c} / \mathrm{kWh}$. In Slovakia Feed-in tariffs varies from $2.6 € \mathrm{c} / \mathrm{kWh}$ for biomass from straw to $15.5 € \mathrm{c} / \mathrm{kWh}$ for geothermal. In Lithuania Feed in tariffs in 2014 were in range from $5.5 € \mathrm{c} / \mathrm{kWh}$ (reconstructed biomass PP with capacity exceeding $5,000 \mathrm{~kW}$ ) to $20.00 € \mathrm{c} / \mathrm{kWh}$ (building-integrated installations of solar energy with capacities up to and including $10 \mathrm{~kW}$ ). Feed-in tariff support scheme was started to be applied in Lithuania from 1 April 2002, and will be managed until 31 December 2020. In Latvia the average feed-in tariff rates paid for operators in 2014 was in range from 10.7 and $11.1 € \mathrm{c} / \mathrm{kWh}$ (wind power plants and large HPP) to 18.5 and $19.5 € \mathrm{c} / \mathrm{kWh}$ for biomass and biogas power plants respectively. In Estonia, electricity generation from renewable energy sources is promoted through a premium tariff. The bonus payment on top of the electricity market price amounts to $5.4 € \mathrm{c} / \mathrm{kWh}$ and does not differ for the individual technologies. However, CHP plants with a production capacity below $10 \mathrm{MW}$ using waste, peat or oil-shale retorting gas are eligible for a tariff amounting to $3.2 € \mathrm{c} / \mathrm{kWh}$. Therefore, the lowest and equal to all technologies feedin tariffs in 2014 were applied in Estonia. The highest feed-in tariffs in the same year were applied in Slovakia and Lithuania. Latvia distinguishes with very high Feed-in tariffs for small hydro and wind energy comparing with other analyzed countries. Lithuania distinguishes with high Feed-in tariffs for solar energy. Therefore again Czech Republic has one of the lowest Feed-in prices among analyzed countries though distinguishes with the highest external costs of atmospheric emissions among selected countries. Conducted analysis allows expecting appropriate dynamics of atmospheric emissions. In the next section of the paper analysis of dynamics of the main atmospheric pollutants emissions will be compared among Baltic States, Czech Republic and Slovakia. 


\begin{tabular}{|c|c|c|c|c|c|}
\hline Renewables & Czech Republic & Slovakia & Lithuania & Latvia & Estonia \\
\hline Wind energy & approx. $7.3 € c / k W h$ & $7.03 € \mathrm{c} / \mathrm{kWh}$ & $\begin{array}{l}\text { Installed capacity (IC) up to } 10 \mathrm{~kW} \text { : } \\
8.1 € \mathrm{C} / \mathrm{kWh} \\
\text { IC exceeding } 10 \mathrm{~kW} \text { up to } 350 \mathrm{~kW} \text { : } \\
7.5 € \mathrm{C} / \mathrm{kWh} \\
\text { IC exceeding } 350 \mathrm{~kW} \text { : } \\
6.4 € \mathrm{C} / \mathrm{kWh}\end{array}$ & $10.7 € \mathrm{c} / \mathrm{kWh}$ & $\begin{array}{l}5.4 € c / k W h \\
\text { Restrictions: the } \\
\text { tariff scheme will be } \\
\text { suspended for the } \\
\text { current calendar } \\
\text { year as soon as } \\
\text { a total of } 600 \mathrm{GWh} \text { of } \\
\text { electricity from wind } \\
\text { energy has already } \\
\text { been supported. }\end{array}$ \\
\hline Solar energy & $\begin{array}{l}\text { IC up to } 5 \mathrm{~kW} \text { approx. } \\
11.1 € \mathrm{C} / \mathrm{kWh} \\
\text { IC up to } 30 \mathrm{~kW} \text { approx. } \\
9.0 € \mathrm{C} / \mathrm{kWh}\end{array}$ & $9.9 € c / k W h$ & $\begin{array}{l}\text { Building-integrated installations: } \\
\text { IC up to and including } 10 \mathrm{~kW}: 20 € c / \mathrm{kWh} \\
\text { IC exceeding } 10 \mathrm{~kW} \text { up to and including } \\
100 \mathrm{~kW}: 18.0 € \mathrm{C} / \mathrm{kWh} \\
\text { IC exceeding } 100 \mathrm{~kW}: 16.8 € \mathrm{C} / \mathrm{kWh} \\
\text { Installations not integrated in buildings: } \\
\text { IC up to } 10 \mathrm{~kW}: 15.6 € C / \mathrm{kWh} \\
\text { IC exceeding } 10 \mathrm{~kW} \text { up to and including } \\
100 \mathrm{~kW}: 14.2 € \mathrm{C} / \mathrm{kWh} \\
\text { IC exceeding } 100 \mathrm{~kW}: 13.3 € \mathrm{C} / \mathrm{kWh}\end{array}$ & - & $5.4 € \mathrm{c} / \mathrm{kWh}$ \\
\hline $\begin{array}{l}\text { Geothermal } \\
\text { energy }\end{array}$ & approx. $12.0 € \mathrm{c} / \mathrm{kWh}$ & $15.5 € c / k W h$ & - & - & $5.4 € c / k W h$ \\
\hline Biogas & $\begin{array}{l}\text { Landfill gas or } \\
\text { sewage gas: approx. } \\
7.1 € c / k W h \\
\text { Biogas PP up to } \\
100 \mathrm{~kW} \text { of IC: } \\
\text { approx. } 12.9 € c / k W h\end{array}$ & $\begin{array}{l}\text { Landfill gas: } 7.03 € \mathrm{c} / \mathrm{kWh} \\
\text { Biomethane produced from } \\
\text { biogas using anaerobic } \\
\text { digestion up to IC of } 1 \mathrm{MW}: \\
10.8 € \mathrm{c} / \mathrm{kWh} \\
\text { Biogas PP using anaerobic } \\
\text { digestion IC up to of } 250 \mathrm{~kW}: \\
12.6 € \mathrm{c} / \mathrm{kWh} \mathrm{IC} \text { from } 250 \mathrm{~kW}- \\
500 \mathrm{~kW}: 11.9 € \mathrm{c} / \mathrm{kWh} \\
\mathrm{IC} \text { from } 500 \mathrm{~kW} \text { : to } 750 \mathrm{~kW}: \\
11.1 € \mathrm{c} / \mathrm{kWh} \\
\mathrm{IC} \text { exceeding } 750 \mathrm{~kW}: \\
10.7 € c / \mathrm{kWh} \\
\text { Biogas produced through } \\
\text { thermochemical conversion: } \\
12.3 € \mathrm{c} / \mathrm{kWh} \\
\text { Biogas produced through } \\
\text { anaerobic digestion of bio- } \\
\text { degradable waste: } 11.9 € c / \mathrm{kWh}\end{array}$ & 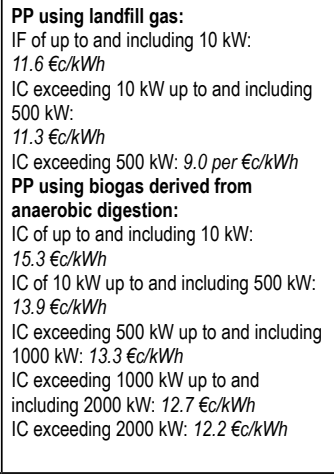 & $5.4 € \mathrm{c} / \mathrm{kWh}$ & $5.4 € \mathrm{c} / \mathrm{kWh}$ \\
\hline Hydro-power & $\begin{array}{l}\text { Small and } \\
\text { reconstructed HPP } \\
\text { approx. } 9.1 € \mathrm{c} / \mathrm{kWh} \\
\text { Small HPP at new } \\
\text { locations: approx } \\
11.8 € c / k W h\end{array}$ & $\begin{array}{l}\text { IC up to } 100 \mathrm{~kW}: 11.13 € \mathrm{c} / \mathrm{kWh} \\
\text { IC from } 100 \text { to } 200 \mathrm{~kW} \text { : } \\
10.9 € \mathrm{c} / \mathrm{kWh} \\
\text { IC from } 200 \text { to } 500 \mathrm{~kW} \text { : } \\
10.7 € \mathrm{c} / \mathrm{kWh} \\
\text { IC from } 500 \mathrm{~kW} \text { to } 1 \mathrm{MW} \text { : } \\
10.52 € \mathrm{C} / \mathrm{kWh} \\
\text { IC from } 1 \mathrm{MW} \text { to } 5 \mathrm{MW} \text { : } \\
9.8 € \mathrm{C} / \mathrm{kWh}\end{array}$ & $\begin{array}{l}\text { IC of up to and including } 10 \mathrm{~kW} \text { : } \\
7.8 € \mathrm{c} / \mathrm{kWh} \\
\text { IC exceeding } 10 \mathrm{~kW} \text { up to and including } \\
1000 \mathrm{~kW}: 7.0 € \mathrm{c} / \mathrm{kWh} \\
\text { IC exceeding } 1000 \mathrm{~kW}: 6.4 € \mathrm{c} / \mathrm{kWh}\end{array}$ & $\begin{array}{l}\text { Small HPP }(I C<10 \\
\text { MW): } 18.1 € \mathrm{C} / \mathrm{kWh} \\
\mathrm{HPPs}(I \mathrm{IC}<=4 \mathrm{MW}): \\
14.5 € \mathrm{CC} / \mathrm{kWh} \\
\mathrm{HPPs}(\mathrm{IC}>4 \mathrm{MW}): \\
11.1 € \mathrm{C} / \mathrm{kWh}\end{array}$ & $5.4 € \mathrm{c} / \mathrm{kWh}$ \\
\hline Biomass & $\begin{array}{l}\text { Tariff varies according } \\
\text { to the technology used } \\
\text { approx. 4.8-12.1 } € \mathrm{cl} \\
\text { kWh }\end{array}$ & $\begin{array}{l}\text { Designated biomass: } 9.2 € \mathrm{c} / \mathrm{kWh} \\
\text { Other biomass from waste: } \\
10.1 € \mathrm{c} / \mathrm{kWh} \text { Biomass from } \\
\text { straw: } 2.6 € \mathrm{c} / \mathrm{kWh} \\
\text { Bioliquids: } 9.4 € \mathrm{c} / \mathrm{kWh}\end{array}$ & $\begin{array}{l}\text { New PPusing biomass: } \\
\text { IC of up to and including } 10 \mathrm{~kW} \text { : } \\
8.7 € C / \mathrm{kWh} \text {; } \\
\text { PP using biomass: } \\
\text { IC exceeding } 10 \mathrm{~kW} \text { up to } 5000 \mathrm{~kW} \text { : } \\
7.5 € \mathrm{C} / \mathrm{kWh} / \mathrm{C} \\
\text { exceeding } 5000 \mathrm{~kW}: 6.7 € \mathrm{C} / \mathrm{kWh} \\
\text { Reconstructed PP using biomass: } \\
\text { IC of up to and including } 10 \mathrm{~kW} \text { : } \\
7.2 € c / \mathrm{kWh} \\
\text { IC exceeding } 10 \mathrm{~kW} \text { up to and including } \\
5000 \mathrm{~kW}: 6.4 € C / \mathrm{kWh} \\
\text { IC exceeding } 5000 \mathrm{~kW}: 5.5 € c / \mathrm{kWh}\end{array}$ & $18.5 € \mathrm{c} / \mathrm{kWh}$ & $5.4 € c / k W h$ \\
\hline
\end{tabular}




\section{Atmospheric Pollution in Baltic States, Czech Republic and Slovakia}

As the analysis of policies to internalize externalities in energy sector revealed quite different situation in Baltic States and Czech Republic and Slovakia it is necessary to analyse dynamics of atmospheric pollution in selected countries in order to define how the progress achieved in internalizing external costs of energy generation impacts dynamics of atmospheric emissions in these countries. In Figure 2 the dynamics of urban population exposure to air pollution by ozone in Baltic States, Czech Republic, Slovakia and EU-27 is presented.

\section{Fig. 2: Dynamics of urban population exposure to air pollution by ozone in Baltic States, Czech Republic, Slovakia and EU-27 in percentage, $2004=100 \%$}

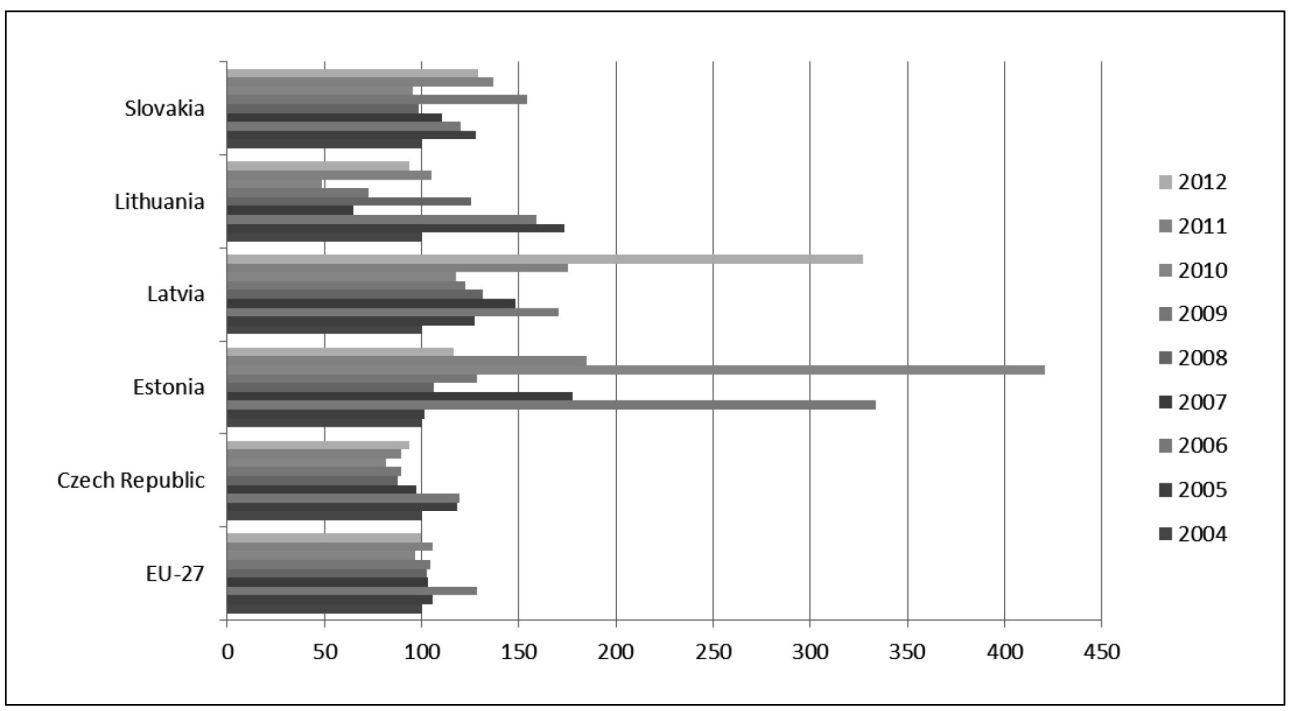

As it can be seen in Figure 2, dynamics of urban population exposure to air pollution by ozone differs significantly between particular countries. According to data, highest degree of urban population exposure was in Estonia in 2010, while the lowest grade was observed in Lithuania in the same year. On the level of EU-27 countries, highest degree of urban population exposure was captured in 2006 . In general positive trends in reduction of exposure to air pollution by ozone can be noticed in all countries except Latvia. In Czech Republic the increase of exposure to air pollution by ozone can be noticed in 2005-2006 and also some increase in 2012 is also obvious.

NOx is one of the major anthropogenic pollutants related with energy production and consumption. Dynamics of NOx emissions in Baltic States, Czech Republic and Slovakia are presented in Figure 3.

In Figure 3, data of emissions of nitrogen oxides (NOx) in Baltic States, Czech Republic, Slovakia and EU-27 is not as scattered as data in Figure 4. Therefore, significant changes are not exactly noticeable. Nonetheless, EU-27 data dynamics suggests emissions of nitrogen oxides (NOx) by source sector declined each year by approximately same percentage and in 2012 was about $70.9 \%$ while compared to 2004 data. In all analyzed countries the trend of decline in NOx emissions can be noticed since 2044 however the most significant declined can be noticed in Czech Republic and Slovakia. Therefore quite low pollution taxes for NOx 

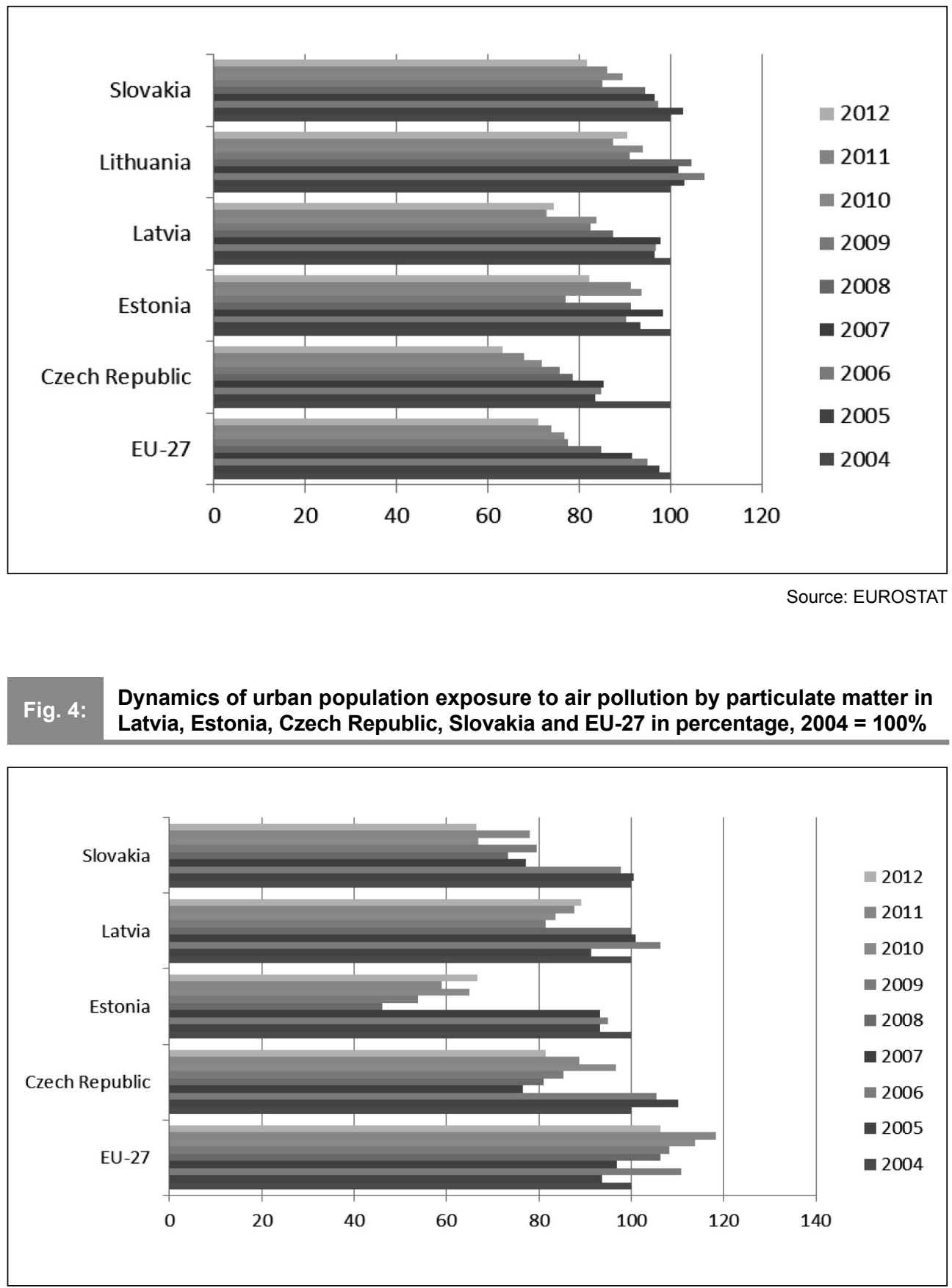


\section{Ekonomie}

Fig. 5:

Dynamics of emissions of sulphur dioxide (SO2) in Baltic States, Czech Republic, Slovakia and EU-27 in percentage, $2004=100 \%$

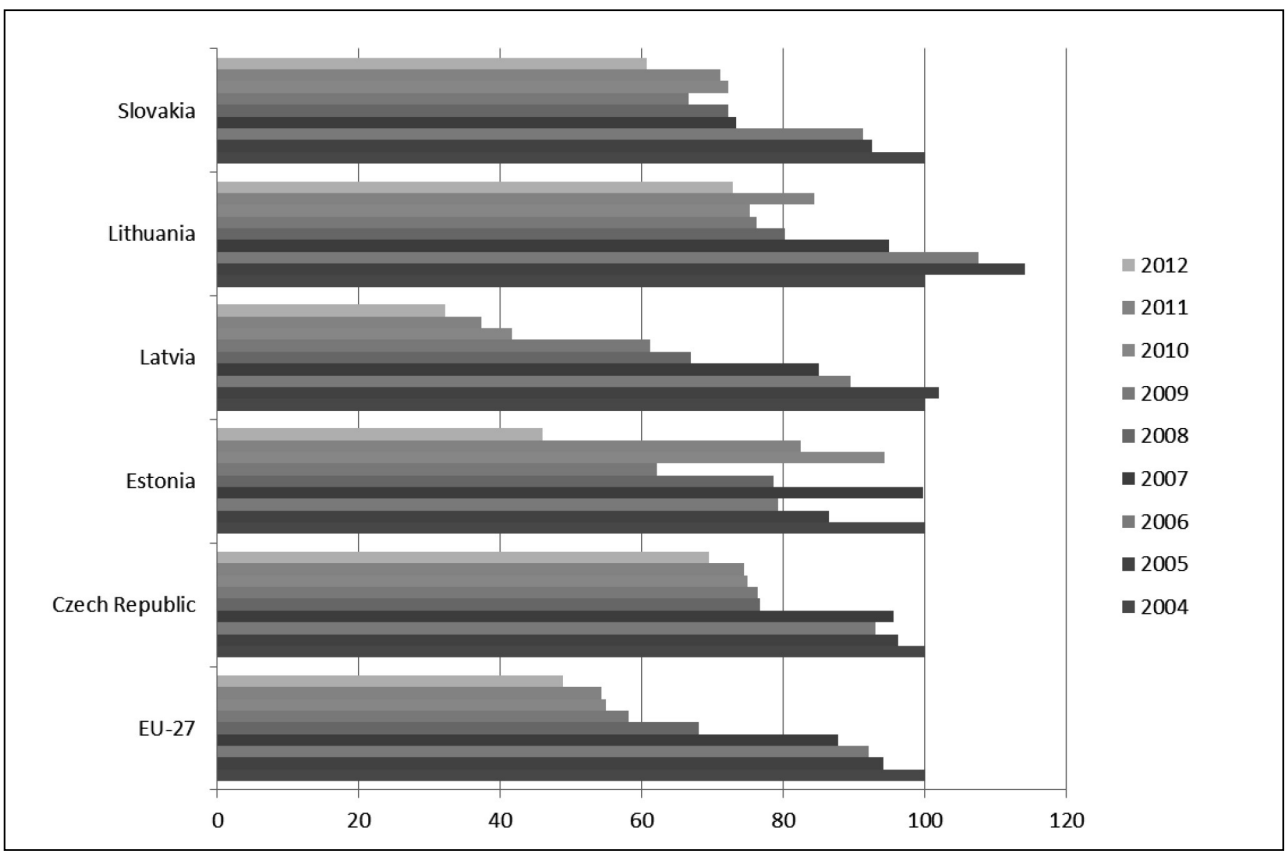

Source: EUROSTAT

Fig. 6:

Dynamics of emissions of non-methane volatile organic compounds (NMVOC) in Baltic States, Czech Republic, Slovakia and EU-27 in percentage, $2004=100 \%$

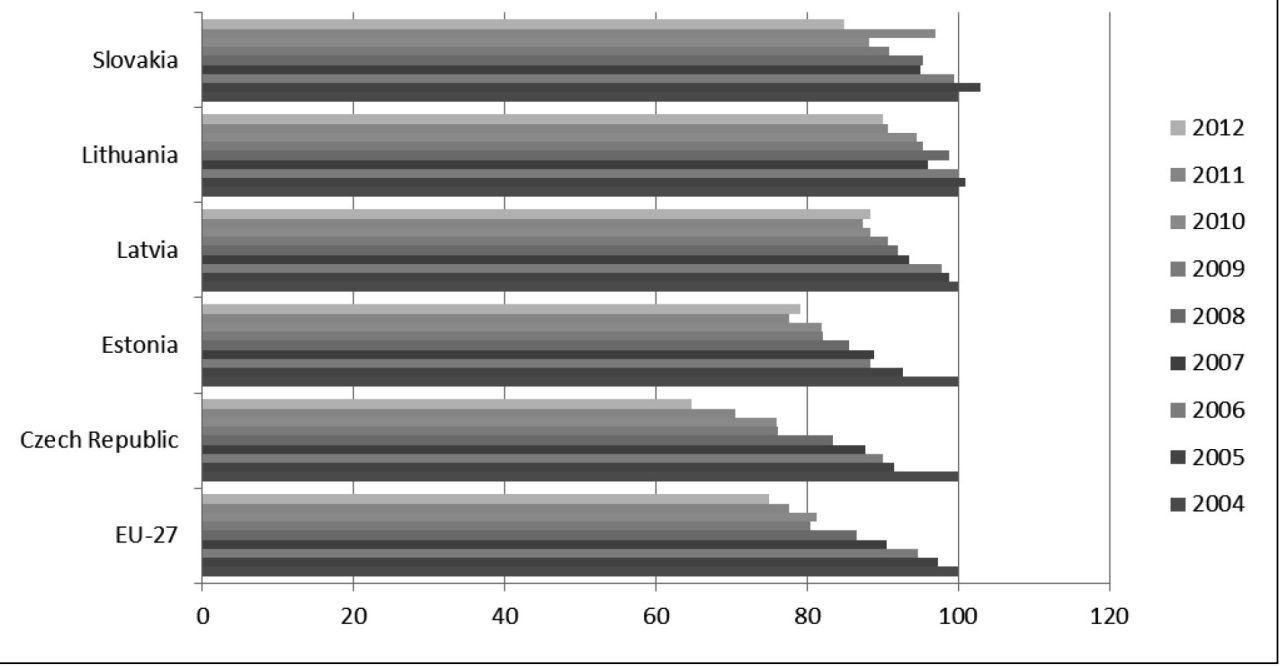


in Czech Republic and low Feed-in prices for renewables didn't have negative impact on reduction of NOx emissions into atmosphere.

Particulates are also one of the major anthropogenic pollutants related with energy production and consumption. Dynamics of PM emissions in Baltic States, Czech Republic and Slovakia are presented in Figure 4.

As one can see from Figure 4 although dynamics of urban population exposure to air pollution by particulate matter differs significantly between particular countries, it can be argued, data of Latvia, Estonia, Czech Republic reflects well on overall data of EU-27. Downward trend can be seen approximately until 2008 and then once again urban population exposure to air pollution by particulate matter starts to increase. Just Slovakia distinguishes among analysed countries with clear trend of PM decrease since 2004. In Czech Republic decrease of PM emissions can be noticed just since 2008. Until economic crisis PM emissions were increasing in this country.

SO2 emissions are also one of the major anthropogenic pollutants related with energy production and consumption. Dynamics of SO2 emissions in Baltic States, Czech Republic and Slovakia are presented in Figure 5.

As Figure 5 demonstrates, dynamics of emissions of sulphur dioxide in Baltic States, Czech Republic, Slovakia and EU-27 is distributed unevenly. Nonetheless, on the level of EU-27, significant decreasing trend can be observed. It should be stressed, however, only in Latvia and Lithuania particular data has grown in between 2005 and 2006. Special additions can be observed in Lithuania - in 2005 emissions of sulphur dioxides reached approximately $114 \%$ and in 2006 this value has decreased only by $107 \%$, while at the same time in Latvia it was about $89 \%$ already. Slovakia and Latvia distinguishes from analysed countries with sharp decrease of $\mathrm{SO} 2$ emissions since 2004. In Czech Republic since 2008 SO2 emissions remained stable just in 2012 some reduction can be noticed.

Dynamics of emissions of non-methane volatile organic compounds (NMVOC) in Baltic States, Czech Republic, Slovakia and EU-27 are presented in Figure 6.

As one can see from Figure 6 rather extremely variable data of emissions of nonmethane volatile organic compounds (NMVOC) was monitored in the scale of EU-27, while on the level of individual countries dynamics, although intermittent, is not as evident. As the largest increase was observed in Slovakia in 2005 , overall, it can be stated, scale of emissions of non-methane volatile organic compounds (NMVOC) has been declining over the years, and e.g. in Czech Republic in 2012 was about $64 \%$. In Slovakia and Estonia NMVOC emissions also were by almost $20 \%$ lower in 2012 comparing to 2004.

\section{Conclusions}

External costs are the main market failure in energy sector and make a significant part of total social costs. Energy technologies distinguishes with different levels of external costs of atmospheric pollution. In the case of renewable energy sources (RES), are quite low, while major damages, such as atmospheric pollution, acid deposition, adverse health effects of pollution, loss of crop yield and biodiversity, soiling of building facades, accelerated corrosion of materials, and various climate change impacts caused by the production of traditional electricity are not reflected in the prices of fossil. Therefore special policies are necessary to internalize external costs and therefore to reduce atmospheric pollution caused by energy generation and consumption.

The highest external costs of atmospheric emissions can be noticed on Czech Republic following by Slovakia. This is mainly related with the highest GDP and income per capita adjusted at PPP. The lowest external costs were determined in Lithuania and Estonia however in Estonia human health and loss of biodiversity costs related to $\mathrm{NH} 3$ are the highest among Baltic States. Lithuania distinguishes with quite high human health and biodiversity loss costs related to NOx comparing with other Baltic States.

Countries having higher external costs of atmospheric emissions are supposed to have higher pollution taxes aiming at internalization of external costs of atmospheric emissions. Though there are other policies and measures to promote renewables and internalize external costs such as energy taxes, use of subsides for RES from EU Structural Funds etc. pollution taxes relevant to energy sector and feed-in tariffs for RES are the main measures to internalize external costs of atmospheric pollution.

The conducted analysis showed that the highest rates of pollution taxes are imposed in 
Estonia. This also provides for high shares of environmental taxes as the percentages of GDP in this country. Czech Republic distinguishes with quite low rates of pollution taxes among analysed countries though country has one of the highest external costs of atmospheric emissions.

Conducted analysis indicated that the lowest and equal to all technologies feed-in tariffs in 2014 were applied in Estonia. The highest feed-in tariffs in the same year were applied in Slovakia and Lithuania. Latvia distinguishes with very high Feed-in tariffs for small hydro and wind energy comparing with other analyzed countries. Lithuania distinguishes with high Feed-in tariffs for solar energy. Therefore again Czech Republic has one of the lowest Feedin prices among analyzed countries though distinguishes with the highest external costs of atmospheric emissions among selected countries.

Analysis of the atmospheric pollutants emissions in five selected countries indicated that the positive trends of atmospheric emission reduction can be noticed since 2004 in all analysed countries however countries have achieved different results in reducing specific atmospheric pollutants emissions. Latvia distinguishes with very good results achieved in reduction of $\mathrm{SO} 2$ and NOx emissions, but the urban population exposure to air pollution by ozone has increased significantly in 2012 in Latvia. Estonia distinguishes from other analysed countries with achieved good results in reduction of emissions of non-methane volatile organic compounds and SO2 emissions. Czech Republic has achieved good results in reduction of emissions of NOx though the pollution tax rate for NOx emissions were the lowest in Czech Republic. This indicates that the degree of internalization of external costs related to specific pollutants does not necessary imply emission reduction of these pollutants as other factors (subsidies, tax allowances etc.) also play an important role.

The further analysis and research are necessary to define the main drivers of atmospheric emissions in the countries having in mind that not the high tax rates on pollution play the major role in emission reduction therefore alternative policies and measures need to be explored further to develop viable recommendations for internalization of externalities in energy sector.

\section{References}

Blumberga, D., Barisa, A., Veidenbergs, I., Blumberga, A., \& Kuhi-Thalfeldt, R. (2014). Evaluation of RES-E support policies in the Baltic States. In 9th International Conference "Environmental Engineering". Selected papers (1-9). Vilnius: Vilnius Gediminas Technical University Press Technika. doi:10.3846/ enviro.2014.255.

Bridges, A., Felder, F. A., McKelvey, K., \& Niyogi, I. (2015). Uncertainty in energy planning: Estimating the health impacts of air pollution from fossil fuel electricity generation. Energy Research \& Social Science, 6, 74-77. doi:10.1016/j.erss.2014.12.002.

CASES (Cost Assessment of Sustainable Energy System). (2008). Development of a set of full cost estimates of the use of different energy sources and its comparative assessment in EU countries (D.6.1 [WP 6 report]). Brussels: EC.

Chiroleu-Assouline, M., \& Fodha, M. (2014). From regressive pollution taxes to progressive environmental tax reforms. European Economic Revue, 69(July), 126-142. doi:10.1016/j. euroecorev.2013.12.006.

Del Rio, P., \& Gual, M. A. (2007). An integrated assessment of feed-in tariff in Spain. Energy Policy, 35(January), 994-1012. doi:10.1016/j.enpol.2013.08.096.

$$
\text { European Commission. }
$$

Externalities of fuel cycles 'ExternE' Project. National Implementation Programme. DGXII, Science, Research and Development, JOULE. Brussels: EC

European Commission. (2003). External costs: research results on socio-environmental damages due to electricity and transport. Directorate-General for Research, Directorate J-Energy. Brussels: EC.

European Commission. (2005). ExternE - externalities of energy: methodology 2005 update. Directorate-General for Research, Sustainable Energy Systems. Brussels: EC.

Fagiani, R., Richstein, J. C., Hakvoort R., \& De Vries, L. (2014). The dynamic impact of carbon reduction and renewable support policies. Utilities Policy, 28(March), 28-41. doi:10.1016/j.jup.2013.11.004.

Fouquet, D. (2013). Policy instruments for renewable energy - From a European perspective. Renewable Energy, 49(January), 15-18. doi:10.1016/j.renene.2012.01.075.

Fouquet, R., Slade, R., Karakoussis, V., Gross, R., Bauen, A., \& Anderson, D. (2001). 
External costs and environmental policy in the United Kingdom and the European Union (Occasional Paper 3). London: Imperial College of Science Technology and Medicine. Centre for Energy Policy and Technology. Retrieved from http://www3.imperial.ac.uk/portal/pls/portallive/ docs/1/7294722.PDF.

Georgakellos, D. A. (2010). Impact of a possible environmental externalities internalisation on energy prices: The case of the greenhouse gases from the Greek electricity sector. Energy Economics, 32(1), 202-209. doi:10.1016/j.eneco.2009.05.010.

Hsu, S., Walters, J., \& Purgas, A. (2008). Pollution tax heuristics: An empirical study of willingness to pay higher gasoline taxes. Energy Policy, 36(9), 3612-3619. doi:10.1016/j. enpol.2008.06.010.

Jenner, S., Groba, F., \& Indvik, J. (2013). Assessing the strength and effectiveness of renewable electricity feed-in tariffs in European Union countries. Energy Policy, 52(January), 385-401. doi:10.1016/j.enpol.2012.09.046.

Krewitt, W. (2002). External costs of energy - do the answers match the question? Looking back at 10 years of ExternE. Energy Policy, 30(10), 839-848. doi:10.1016/S03014215(01)00140-9.

Longo, A., Markandya, A., \& Petrucci, M. (2008). The internalization of externalities in the production of electricity: Willingness to pay for the attributes of a policy for renewable energy. Ecological Economics, 67(1), 140-152. doi:10.1016/j.ecolecon.2007.12.006.

Máca, V., Melichar, J., \& Ščasný, M. (2012). Internalization of External Costs of Energy Generation in Central and Eastern European Countries. Journal of Environment \& Development, 21(2), 181-197. doi: $10.1177 / 1070496512442504$.

Markandya, A. (2003). Expected external costs and their structure characterizing electricity options and their role in the strategic assessment of these options. In Conference on Electric Power Supply in the 21st Century. Warsaw.

Mirasgedis, S., Dialoulaki, D., Papagiannakis, L., \& Zervos, A. (2000). Impact of social costing on the competitiveness of renewable energies: the case of Crete. Energy Policy, 28(1), 65-73. doi:10.1016/S03014215(99)00082-8.

Parry, I. W. H. (1995). Pollution taxes and Revenue Recycling. Journal of Environmental Economic and Management, 29(3), S64-S77. doi:10.1006/jeem.1995.1061.

Rafaj, P., \& Kypreos, S. (2007). Internalisation of external cost in the power generation sector: Analysis with global multiregional MARKAL model. Energy Policy, 35(2), 828-843. doi:10.1016/j.enpol.2006.03.003.

Streimikiene, D., \& Alisauskaite-Seskiene, I. (2014). External costs of electricity generation options in Lithuania. Renewable Energy, 64(April), 215-224. doi:10.1016/j. renene.2013.11.012.

Streimikiene, D., \& Balezentiene, L. (2012). Assessment of Electricity Generation Technologies Based on GHG Emission Reduction Potential and Costs. Transformations in Business and Economics, 11(2A), 333-344.

Streimikiene, D., \& Sarvutyte-Grigaliuniene, M. (2012). Impact of renewables on employment in Lithuania. Transformations in Business and Economics, 11(1), 167-184.

Vasauskaite, J., \& Streimikiene, D. (2014). Review of Energy Efficiency Policies in Lithuania. Transformations in Business \& Economics, 13(3C), 628-643.

Verbruggen, A., \& Lauber, V. (2012). Assessing the performance of renewable electricity support instruments. Energy Policy, 45(June), 635-644. doi:10.1016/j. enpol.2012.03.014.

prof. Dalia Štreimikienè, Ph.D. Mykolas Romeris University Faculty of Economics and Finance Management dalia.streimikiene@khf.vu.It

Ilona Ališauskaitè-Šeškienè Lithuanian Energy Institute Laboratory of Energy Systems Research seskiene@lei.It 


\section{Abstract}

\section{COMPARATIVE ASSESSMENT OF EXTERNAL COSTS AND POLLUTION TAXES IN BALTIC STATES, CZECH REPUBLIC AND SLOVAKIA}

\section{Dalia Štreimikienè, Ilona Ališauskaitè-Šeškienè}

External costs are the main market failure. Pollution taxes and other flexible market instruments are applied to internalise external costs of atmospheric emissions. Subsidies to renewable energy technologies in the form of Feed-in prices are also applied to internalize positive external benefits associated with use of renewable energy sources for energy generation as these technologies have lower life-cycle emissions of classical pollutants and GHG emissions in comparison with fossil fuel based energy generation technologies.

The paper reviews and compares external costs of atmospheric pollution and pollution taxes in Baltic States, Czech Republic and Slovakia and assesses the level of internalization of external costs and their impact on atmospheric emissions of classical pollutants in these countries. The literature review allows generalizing results of external costs assessment and their internalization issues. The paper analyses and compares external costs of atmospheric pollution in Baltic States, Czech Republic and Slovakia together with atmospheric pollution taxes and other policy measures used to internalise external costs of atmospheric pollution in Baltic States and Czech Republic and Slovakia. The analysis of trends of atmospheric pollution by classical pollutants in Baltic States and Czech Republic and Slovakia is provided and policy recommendations based on the main findings of analysis conducted were developed.

Key Words: External costs, atmospheric emissions, environmental taxes, Baltic States, Czech Republic, Slovakia.

JEL Classification: M12, M53.

DOI: 10.15240/tul/001/2016-4-001 